\title{
A New Species of the Genus Iotrochota (Demospongiae: Poecilosclerida: Iotrochotidae) from Korea
}

\author{
Mi Jeong Kim and Chung Ja Sim* \\ Department of Biological Sciences, College of Life Science and Nano Technology, \\ Hannam University, Daejeon 305-811, Korea
}

\begin{abstract}
A new species Iotrochota rutzleri n. sp. (Demospongiae: Poecilosclerida: Iotrochotidae) was collected from intertidal zone, Sinyangri, Seongsanpo, Jejudo Island, Korea during 2008-2009. Iotrochota rutzleri $\mathrm{n}$. sp. is similar to I. baculifera Ridley, 1884 in composition of spicules and skeletal structure. However, it is different in size of spicules, growth form and colour. All spicules of this new species are smaller than those of the latter.
\end{abstract}

Keywords: lotrochota, lotrochotidae, Korea

\section{INTRODUCTION}

The family Iotrochotidae Dendy, 1922 contains six genera, Amphiastrella, Hymetrochota, Iotroata, Iotrochopsamma, Rotuloplocamia, and Iotrochota. This family is characterized by birotulae. The genus Iotrochota consist of style and strongyle as megascleres. Ectosomal skeleton formed by an organic crust with scattered loose megascleres. Choanosomal skeleton has regular regulation of thick spicule tracts. Spongin is usually dark pigmented. About 15 species of this genus Iotrochota have been reported worldwide (Hooper and van Soest, 2002). Only one species of Iotrochota has been reported from Korean waters (Rho and Sim, 1976). This new sponge was collected by hand from intertidal zone, Sinyangri, Seongsanpo, Jejudo Island, Korea. All procedures were followed the methods of Rützler (1978) and Kim and Sim (2005). The materials examined in this study were deposited in the Natural History Museum, Hannam University, Daejeon, Korea.

\section{SYSTEMATIC ACCOUNTS}

Phylum Porifera Grant, 1836

Class Demospongiae Sollas, 1885

Order Poecilosclerida Topsent, 1928

Suborder Myxillina Hajdu, Van Soest \& Hooper, 1994

Family Iotrochotidae Dendy, 1922

*To whom correspondence should be addressed

Tel: 82-42-629-8455, Fax: 82-42-629-8751

E-mail: cjsim@hnu.kr
${ }^{1} *$ Iotrochota rutzleri n. sp. (Figs. 1, 2)

Material examined. Holotype (Por. 102), Intertidal zone, Sinyangri, Seongsanpo, Jejudo Island, 15, Oct. 2008, C.J. Sim, Paratype (Por. 102-1), Intertidal zone, Sinyangri, Seongsanpo, Jejudo Island, 4, Jun. 2009, C.J. Sim.

Description. Thinly encrusting on the rock, size up to $5 \times 5$ $\mathrm{cm}, 5 \mathrm{~mm}$ thick. Surface rough owing to projecting bundle of spicules, partially covered with thin membrane. Oscules and pores invisible. Colour black in life. Texture smooth and slightly compressible. Skeleton regular reticulation of thick spicule tracts, mesh size 500-600 $\mu \mathrm{m}$. Spicules two types of megascleres with style and strongyle. Strongyles more numerous in spongin, styles more numerous in fibre. Microscleres umbrella-shaped birotulae with six clads.

Spicules.

Megascleres

Thick style ….................... 135-170 ×5-10 $\mu \mathrm{m}$

Thin style $\ldots \ldots \ldots \ldots \ldots \ldots \ldots \ldots \ldots \ldots \ldots \ldots \ldots \ldots \ldots \ldots$

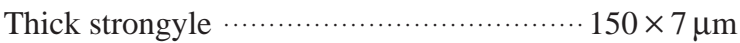

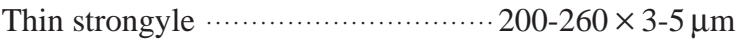

Microscleres

Birotulae ….............................. 12.5-15 $\mu \mathrm{m}$

Remarks. This species is similar to Iotrochota baculifera Ridley, 1884 in composition of spicules and skeletal structure but it differs in size of spicules, growth form and colour. All spicules of this new species are smaller than those of the latter. Also, megascleres are differentiated in longer-thinner and shorter-thicker categories. The growth form in new species is encrusting but erect in the latter. The colour is black in new species but dark crimson in the latter (Table 1). 


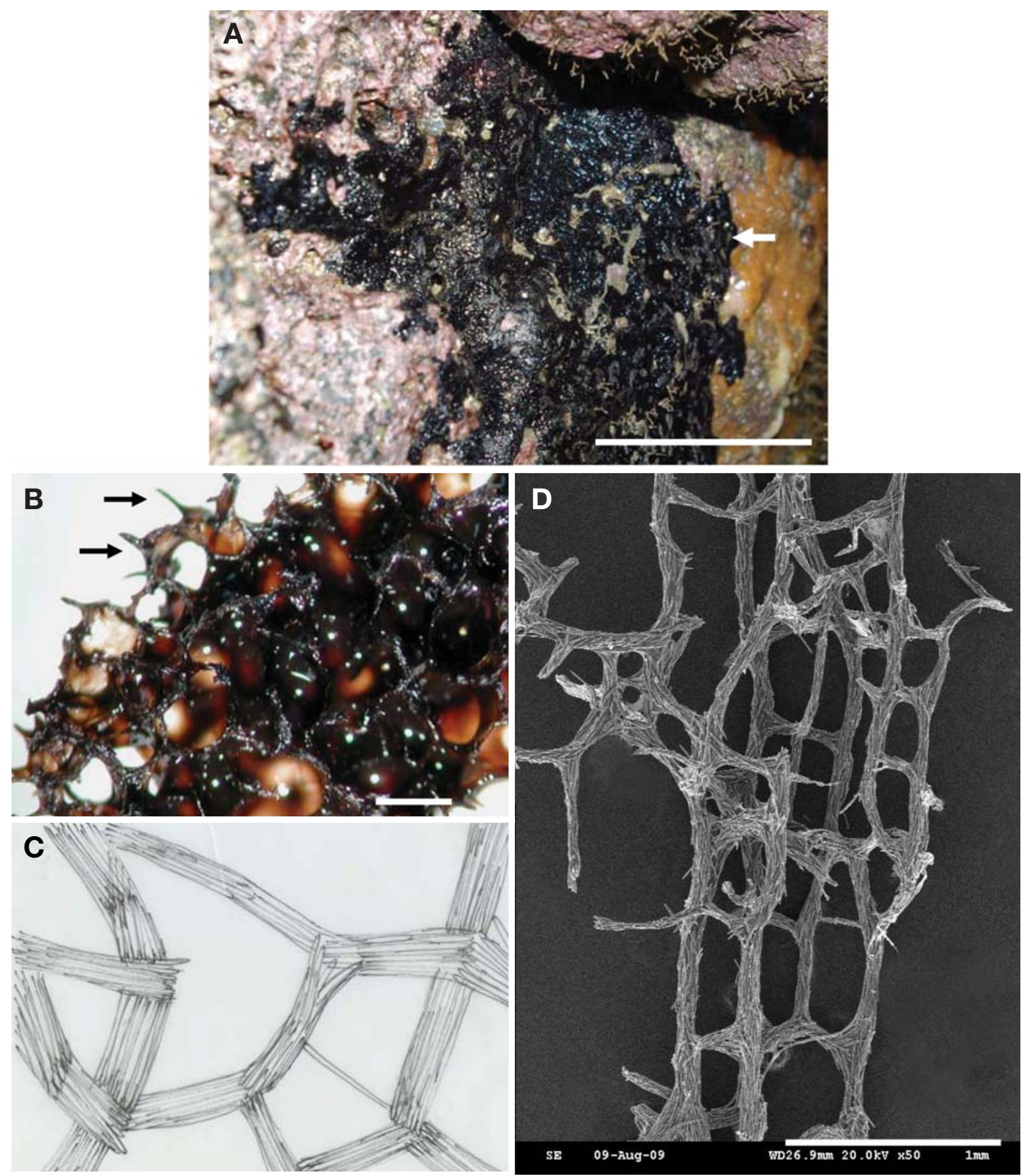

Fig. 1. Iotrochota rutzleri n. sp. A, entire animal (arrow); B, surface with spicule bundle (arrow); C, spicule tracts; D, skeletal structure. Scale bars $=2 \mathrm{~cm}(A) ; 1 \mathrm{~cm}(B) ; 1 \mathrm{~mm}(D)$.

\section{ACKNOWLEDGEMENTS}

This research was supported by a grant from Marine Biotechnology Programme funded by Ministry of Land, Transport and Maritime Affairs of Korean Government. We thank Dr. G.J. Bakus, Department of Biological Science, University of Southern California for his advice and review of the manuscript. 

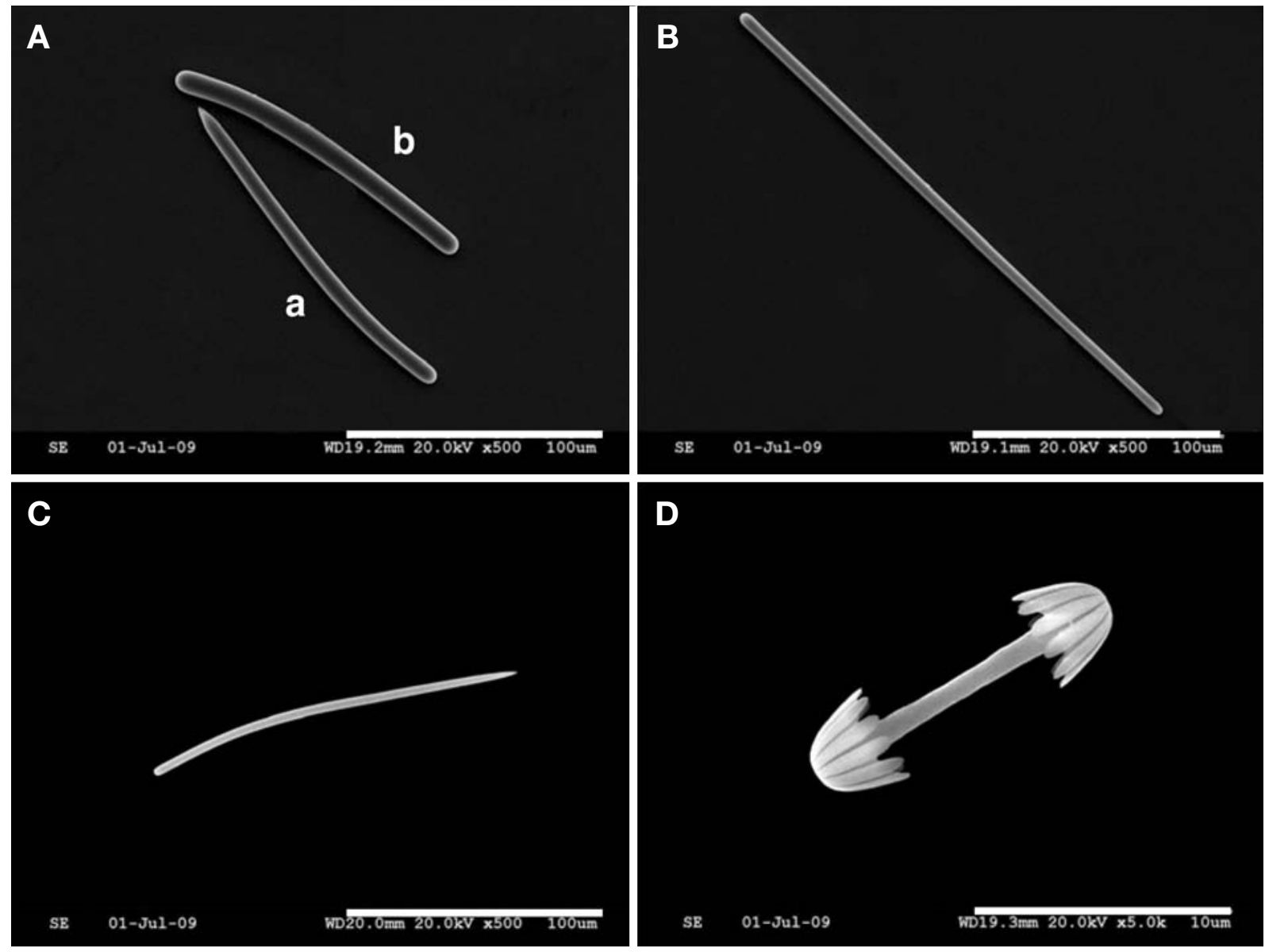

Fig. 2. Iotrochota rutzleri n. sp. A, a, thick style; $b$, thick strongyle; $B$, thin strongyle; $C$, thin style; $D$, birotulae. Scale bars $=100$ $\mu \mathrm{m}(\mathrm{A}-\mathrm{C}) ; 10 \mu \mathrm{m}(\mathrm{D})$.

Table 1. The characters comparison between I. rutzleri n. sp. and I. baculifera.

\begin{tabular}{|c|c|c|c|c|}
\hline \multirow{2}{*}{\multicolumn{3}{|c|}{ Characters }} & \multicolumn{2}{|c|}{ Species } \\
\hline & & & I. rutzleri $\mathrm{n} . \mathrm{sp}$. & I. baculifera Ridley, 1884 \\
\hline \multicolumn{2}{|c|}{ Growth form } & & Thinly encrusting & Erect in subcylindrical lobes \\
\hline \multicolumn{2}{|c|}{ Colour } & & Black & Dark crimson \\
\hline \multirow{5}{*}{ Spicules $(\mu \mathrm{m})$} & \multirow{2}{*}{ Style } & Thick & $135-170 \times 5-10$ & $200 \times 9.5-12.7$ \\
\hline & & Thin & $120-150 \times 2.5$ & - \\
\hline & \multirow{2}{*}{ Strongyle } & Thick & $150 \times 7$ & $220-280 \times 6.3$ \\
\hline & & Thin & $200-260 \times 3-5$ & - \\
\hline & \multicolumn{2}{|c|}{ Birotulae } & $12.5-15$ & 16 \\
\hline
\end{tabular}

\section{REFERENCES}

Hooper, J.N.A., 1996. Revisoin of Microcionidae (Porifera: Poecilosclerida: Demospongiae), with description of Australian species. Mem. of the Queensland Mus., 40: 1-626.

Hooper, J.N.A. and W.M. van Soest, 2002. Systema Porifera:
A guide to the classification of sponges. Kluwer Academic/ Plenum Publishers Press, USA, pp. 1-1101.

Kim, H.J. and C.J. Sim, 2005. Two new marine sponges of genus Clathria (Clathria) (Poecilosclerida: Microcionidae) from Korea. Korean J. Syst. Zool., 21: 111-122.

Rho, B.J. and C.J. Sim, 1976. On the classification and the 
Distribution of the Marine Benthic Animals in Korea (4). Sponges. J. Kor. Res. Inst. Bet. Liv., 17: 93-111.

Ridley, S.O., 1884. Spongiida. Rep., 2001. collec. Indo pacific Ocean during voyage of H.M.S. Alert. 1881-1882

Rützler, K., 1978. Sponges in coral reefs. In: Coral Reefs: Re- search Methods (Eds., D.R. Stoddart and R.E. Johannes). Monogr. Oceanogr. Neth Unesco, 5: 299-313.

Received February 12, 2010 Accepted March 11, 2010 